\title{
Effect of pectinase treatment on extraction yield and physicochemical properties of Aronia juice
}

\author{
Dong-Hwan Kim ${ }^{1}$, Jun-Su Choi ${ }^{1}$, Min-Hyung Lee ${ }^{1}$, Han-Hee Jang ${ }^{1}$, Han-Sol Kim ${ }^{1}$, \\ Do-Youn Kim ${ }^{1}$, Soo-Hwan Yeo ${ }^{2}$, Heui-Dong Park ${ }^{1 *}$ \\ ${ }^{1}$ Department of Food Science and Technology, Kyungpook National University, School of food science and biotechnology, \\ Daegu 41566, Korea \\ ${ }^{2}$ Fermented Food Science Division, Depertment of Agro-food Resources, NIAS, RDA, 166, Nongsaengmyeong-ro, Iseo-myeon, \\ Wanju 55365, Korea
}

\section{Pectinase 처리가 아로니아의 착즙 수율에 미치는 영향}

\author{
김동환 ${ }^{1} \cdot$ 최준수 ${ }^{1} \cdot$ 이민형 ${ }^{1} \cdot$ 장한희 $^{1} \cdot$ 김한솔 $^{1} \cdot$ 김도연 $^{1} \cdot$ 여수환 ${ }^{2} \cdot$ 박희동 ${ }^{1 *}$ \\ ${ }^{1}$ 경북대학교 식품공학부 식품생물공학전공, ${ }^{2}$ 농촌진흥청 국립농업과학원 농식품자원부 발효식품과
}

\begin{abstract}
The main objective of this study was to investigate the effects of various commercial pectin enzyme treatments on juice yield from Aronia fruits (Aronia melanocarpa) as well as changes in physicochemical properties such as $\mathrm{pH}$, total acid, reducing sugar, soluble solid, total anthocyanin, total phenolic compounds, and DPPH radical scavenging activity. Different types and reaction conditions of pectinase were also investigated in order to improve extraction yield of Aronia juice. The optimal conditions of enzyme treatment were $0.1 \%$ of concentration (w/w) at $50^{\circ} \mathrm{C}$ for 120 min. Among enzymes used in this study, extraction yield with Rapidase Press $L$ treatment from Aronia juice was the highest and resulted in a significant increase in juice from 51.0 to $69.1 \%$. Rapidase C80 MAX showed $68.83 \%$ extraction yield while Plantase TCL showed $66.70 \%$ extraction yield. Reducing sugar and soluble solid contents increased after enzyme treatment. Total acids also slightly increased after enzyme reaction. No significant difference was observed in $\mathrm{pH}$ regardless of pectin enzyme treatment. However, enzyme treatment resulted in an increase in total phenolic compounds, total anthocyanin, and DPPH radical scavenging in Aronia juice compared to the juice prepared juice.
\end{abstract}

Key words : Aronia melanocarpa, Pectinase, Extraction yield, DPPH radical scavenging activity

\begin{abstract}
서 론
아로니아(Aronia melanocarpa)는 장미과에 속하는 베리 류로 북부 아메리카 지역에서 자생한다(1). 학명에 따라 black chokeberry(Aronia melanocarpa), red chokeberry(Aronia arbutifolia) 및 puple chokeberry(Aronia prunifolia)로 나누어
\end{abstract}

*Corresponding author. E-mail : hpark@knu.ac.kr Phone : 82-53-950-5774, Fax : 82-53-950-6772

Received 14 December 2016; Revised 19 January 2017; Accepted 1 February 2017.

Copyright (c) The Korean Society of Food Preservation. All rights reserved.
지나, 일반적으로 아로니아(Aronia melanocarpa)에 모두 포 함시킨다(2). 아로니아는 항산화 물질인 안토시아닌 함유 량이 높으며 식이섬유, 엽산, 폴리페놀, 탄닌, 카테킨, 쿼세 틴, 베타카로틴, 유기미네랄, 유기산, 파이토케미컬, 비타민 $\mathrm{A}, \mathrm{C}, \mathrm{E}, \mathrm{B}_{2}$, 그리고 $\mathrm{B}_{12}$ 등 다양한 영양소를 함유하고 있어 건강 증진 효과가 있다고 알려져 있다(3-7). 그 중 폴리페놀 은 우리 몸에 있는 활성산소(reactive oxygen species)를 해가 없는 물질로 바꿔주는 항(抗)산화물질 중 하나이다. 이는 세포의 DNA와 세포막의 산화를 억제하고 활성산소에 의 한 단백질, 지질의 손상을 막아 혈관 손상을 보호한다. 폴리 페놀의 종류는 수천 가지가 넘는데, 안토시아닌은 대표적 인 폴리페놀의 종류 중 하나이다(8). 아로니아의 안토시아 
닌 함량은 $\mathrm{kg}$ 당 7.2-8.0 g 정도 함유되어 있어 다른 베리류 식물보다 비교적 많은 안토시아닌을 함유하고 있다(9). 이 와 같이 아로니아에는 다양한 안토시아닌 계통의 물질들과 폴리페놀 성분이 함유되어 있어 항산화 성분효능이 베리류 중에서 가장 높고 동맥경화, 심혈관질환, 암, 당뇨병, 위염, 알러지성 피부질환 등에 효능이 있는 것으로 보고되어 있다 $(10,11)$. 아로니아의 효능과 관련하여 아로니아 추출물을 화장품 소재로 활용하기 위해 멜라닌 생성 억제 효과, 항산 화, 항염 효과(12)를 확인했으며, 당뇨 유발 쥐 및 고지혈증 유발 쥐에게 아로니아 추출액을 투여하여 혈당 및 지질 저해 효과(13) 및 심혈관질환저해 효과(14-16)를 확인하였 다. 또한 화이트 초콜릿 가나슈의 산패억제 효과(17), 육포 의 기호성과 저장성 효과(18)가 있음을 확인하였다.

아로니아는 맛과 향, 색 뿐만 아니라 다양한 효능으로 최근 현대인들에게 각광받고 있으며, 식품산업뿐만 아니라 의약 바이오산업에도 이용가치가 매우 높다. 하지만 좋은 효능에도 불구하고 타 과실에 비해 낮은 착즙 수율로 인한 비경제적인 단점을 가지고 있기 때문에 이러한 단점을 보완 하기 위한 착즙 수율 향상에 관한 연구가 필요한 실정이다. 현재 베리류 pectinase 착즙 수율분석 선행연구로는 pectinase 효소처리가 블루베리의 과즙 수율에 미치는 영향 (19)과 딸기의 최적발효 조건 설정 및 품질개선 시험(20), pectinase 효소처리가 복분자 과즙의 추출 수율 향상과 알코 올 발효 중 이화학적 특성에 미치는 영향(21) 등이 있다.

본 연구에서는 아로니아의 착즙 수율을 증대하기 위한 목적으로 과실 조직 분해에 관여하는 pectinase 및 복합 pectinase 효소를 이용하여 효소 종류, 농도, 온도 및 처리시 간에 따른 이화학적 변화를 조사하였다.

\section{재료 및 방법}

본 실험에 사용한 아로니아 원료는 2014년 8월 경북 예천 에서 수확한 품종으로 필요에 따라 $4^{\circ} \mathrm{C}$ 의 저온저장고에서 보관하면서 사용하였다. 아로니아 착즙액의 수율을 향상시 키기 위하여 사용한 효소는 DSM Food Specialties(Delf, Netherlands)사의 Rapidase C80 MAX(pectinase+arabinase, unit 132,000 AVJP/g), Rapidase PRESS L(pectinase+ hemicellulase, 180,000 AVJP/g)와 Bision Biochem(Sungnam, Korea)사의 Plantase TCL(pectinase, unit 50,000 AVJP/g) 총 3 종을 사용하였다.

\section{아로니아 과즙 제조 및 착즙수율}

세척한 아로니아를 가정용 착즙기(NJ-9300A, NUC Juicer, Daegu, Korea)를 사용하여 파쇄 후 효소 종류 및 처리시간을 달리하여 반응시킨 후 착즙하였다. 착즙액은 살균된 조밀한 면포로 1 차 여과 후 원심분리 $(9,000 \times g, 10$ $\min$ )하여 실험에 사용하였다. 착즙율은 착즙 후 아로니아 무게/착즙 전 아로니아 무게 비율로 측정하였다.

\section{일반성분 분석}

일반성분 분석은 $\mathrm{AOAC}$ 방법(22)에 따라 행하였다. 수분 함량은 시료 일정량을 칭량 후 상압건조법에 따라 측정하였 고, 조단백질 함량은 Kjeldahl법을 이용하여 단백질 자동분 석장치(Foss Kjeltec 2300, FOSS Co., Hoganas, Sweden)로 측정하였다. 조지방 함량은 Soxhelt 법에 준하여 측정하였 다. 조회분 정량은 직접회화법으로 측정하였다. 탄수화물 함량은 시료의 총 중량에서 수분, 조단백질, 조지방, 그리고 조회분 함량을 뺀 나머지를 함량(\%)으로 표시하였다.

\section{효소처리 조건}

Rapidase C80 MAX, Rapidase PRESS L, 그리고 Plantase $\mathrm{TCL}$ 의 농도를 $0,0.005,0.01,0.05,0.1 \%(\mathrm{v} / \mathrm{w})$ 로 설정한 후 $40,50,60^{\circ} \mathrm{C}$ 에서 $0,30,60,90,120$ 분 동안 각각 반응시켰다.

\section{$\mathrm{pH}$ 및 총산}

$\mathrm{pH}$ 는 $\mathrm{pH}$ meter를(Mettler-Toledo Co., Schwerzenbach, Switzerland)이용하여 측정하였다. 총산은 적절히 희석한 시료 $10 \mathrm{~mL}$ 를 $0.1 \mathrm{~N} \mathrm{NaOH}$ (factor: $1.001 \pm 0.005$ )로 적정하여 아래의 식에 따라 citric acid의 산도지수 0.0064 를 대입한 후 citric acid(\%)로 환산하여 나타내었다.

$$
\text { 총산 }(\%)=\frac{0.1 \mathrm{~N} \mathrm{NaOH}(\mathrm{mL}) \times 0.0064 \times \mathrm{F}}{\operatorname{Sample}(\mathrm{mL})} \times 100 \times \text { 희석배수 }
$$

\section{당도 및 환원당}

당도는 hand refractometer(RA250, ATAGO, Tokyo, Japan)로 측정하였다. 환원당 함량은 dinitrosalicylic acid (23)법에 따라 측정하였다. 시료 $1 \mathrm{~mL}$ 에 DNS 용액 $3 \mathrm{~mL}$ 를 혼합한 후 $95^{\circ} \mathrm{C}$ 에서 5 분간 중탕하여 실온으로 냉각시켰다. UV-visible Spectrophotometer(UV-1601, Shimazdu Co., Kyoto, Japan)를 사용하여 $550 \mathrm{~nm}$ 에서 흡광도를 측정한 후, glucose 표준곡선으로부터 환원당 함량을 환산하였다.

\section{총 페놀성 화합물}

총 페놀성 화합물 함량은 Folin-Denis법(24)에 따라 측정 하였다. 시료 $2 \mathrm{~mL}$ 에 $50 \%$ phenol reagent(Folin-Ciocalteu's reagent) $2 \mathrm{~mL}$ 를 첨가하여 실온에서 3 분간 방치한 뒤, $10 \%$ $\mathrm{Na}_{2} \mathrm{CO}_{3}$ 용액 $2 \mathrm{~mL}$ 를 첨가하였다. 그리고 실온에서 1 시간 방치한 다음, UV-visible Spectrophotometer(UV-1601, Shimazdu Co.)를 이용하여 $700 \mathrm{~nm}$ 에서 흡광도를 측정한 후, tannic acid 표준곡선으로부터 총 페놀성 화합물 함량을 환산하 였다. 


\section{DPPH radical 소거능}

DPPH radical 소거능은 Blois 방법(25)을 변형하여 측정 하였다. 시료 $200 \mu \mathrm{L}$ 에 methanol $2 \mathrm{~mL}$ 와 DPPH 용액 800 $\mu \mathrm{L}$ 를 혼합하여 10 분간 반응시킨 후 UV-visible Spectrophotometer(UV-1601, Shimazdu Co.)를 이용하여 $517 \mathrm{~nm}$ 에서 흡광도를 측정하였다. DPPH radical 소거능(\%) 은 다음식을 이용하여 구하였다.

DPPH radical 소거능(\%)= $\frac{\text { Absorbance of(control-sample) }}{\text { Absorbance of control }} \times 100$

\section{총 안토시아닌}

총 안토시아닌 함량은 Lee 등(26)의 $\mathrm{pH}$ differential method에 따라 UV-visible Spectrophotometer(UV-1601, Shimazdu Co.)를 이용하여 측정하였다. 아로니아 과즙은 $0.025 \mathrm{M}$ potassium chloride buffer( $\mathrm{pH}$ 1.0)와 $0.4 \mathrm{M}$ sodium acetate buffer(pH 4.5)로 $520 \mathrm{~nm}$ 에서 흡광도 값이 0.2-1.4 범위에 들도록 희석한 후 520 및 $700 \mathrm{~nm}$ 에서 흡광도를 측정하였으며 cyanidin-3-glucoside 몰흡광계수( $\varepsilon=26,900$ $\mathrm{L} \cdot \mathrm{M}^{-1} \cdot \mathrm{cm}^{-1}, \mathrm{MW}=449.2 \mathrm{~g} \cdot \mathrm{M}^{-1}$ )로 환산하였다.

\section{통계 처리}

모든 실험 결과는 3회 반복 실험하여 그 결과 값을 평균과 표준편차로 나타내고 SAS 통계처리를 이용한 분산분석 (ANOVA)과 Duncan's multiple range test로 유의성을 검증 하였다( $\mathrm{p}<0.05)$.

\section{결과 및 고찰}

\section{일반성분 함량}

아로니아 원료의 성분분석 결과는 Table 1 과 같다. 아로 니아 과실은 수분 $79.43 \pm 0.03 \%$, 탄수화물 $18.81 \% \pm 0.07 \%$, 조지방 $0.95 \pm 0.10 \%$, 조단백질 $0.47 \pm 0.02 \%$, 조회분 $0.33 \pm$ $0.02 \%$ 순으로 나타났다.

Table 1. Approximately composition of Aronia melanocarpa

\begin{tabular}{cc} 
& \\
\hline Composition & Contents \\
\hline Moisture & $79.43 \pm 0.03^{2)}$ \\
Crude protein & $0.47 \pm 0.02$ \\
Crude lipid & $0.95 \pm 0.10$ \\
Crude ash & $0.33 \pm 0.02$ \\
Carbohydrate $^{1)}$ & $18.81 \pm 0.07$ \\
\hline
\end{tabular}

\footnotetext{
${ }^{1)} 100$-(Sum of moisture, crude protein, crude lipid and crude ash contents)
}

${ }^{2)}$ The values were expressed as mean $\pm \mathrm{SD}(\mathrm{n}=3)$.
아로니아 과즙의 착즙수율 최적조건

아로니아 과즙의 수율 향상을 위해 3종의 pectinase 효소 를 이용하여 착즙수율 최적조건을 조사하였다. 효소종류, 농도 및 온도에 따른 시간별 아로니아 착즙 수율의 변화는 Fig. 1과 같다. 효소 농도를 $0,0.005,0.05,0.1 \%$ 로 달리하여 처리한 아로니아 과즙액을 $40^{\circ} \mathrm{C}, 50^{\circ} \mathrm{C}, 60^{\circ} \mathrm{C}$ 로 온도를 달리 하여 반응시켜 시간에 따른 변화 결과 $0.1 \%, 50^{\circ} \mathrm{C}, 120$ 분 시험구에서 3 종의 pectinase 관련 효소는 높은 착즙 수율을 나타내었다(data not shown). Koo(19)는 블루베리의 효소처 리에 따른 과즙수율에 관한 연구에서 효소반응 $50^{\circ} \mathrm{C}$ 에서 120 분간 효소처리 후 착즙수율이 높아졌다는 연구결과를 보고하였다. 본 연구에서는 효소 처리를 하지 않은 아로니 아 주스의 착즙수율은 51\%로 나타났으며, Rapidase Press $\mathrm{L}$ 의 경우 $0.1 \%(\mathrm{v} / \mathrm{w})$ 의 농도로 $50^{\circ} \mathrm{C}$ 에서 120 분간 반응시킨 실험구의 착즙 수율이 $69.14 \%$ 로 가장 높게 나타났고, 같은
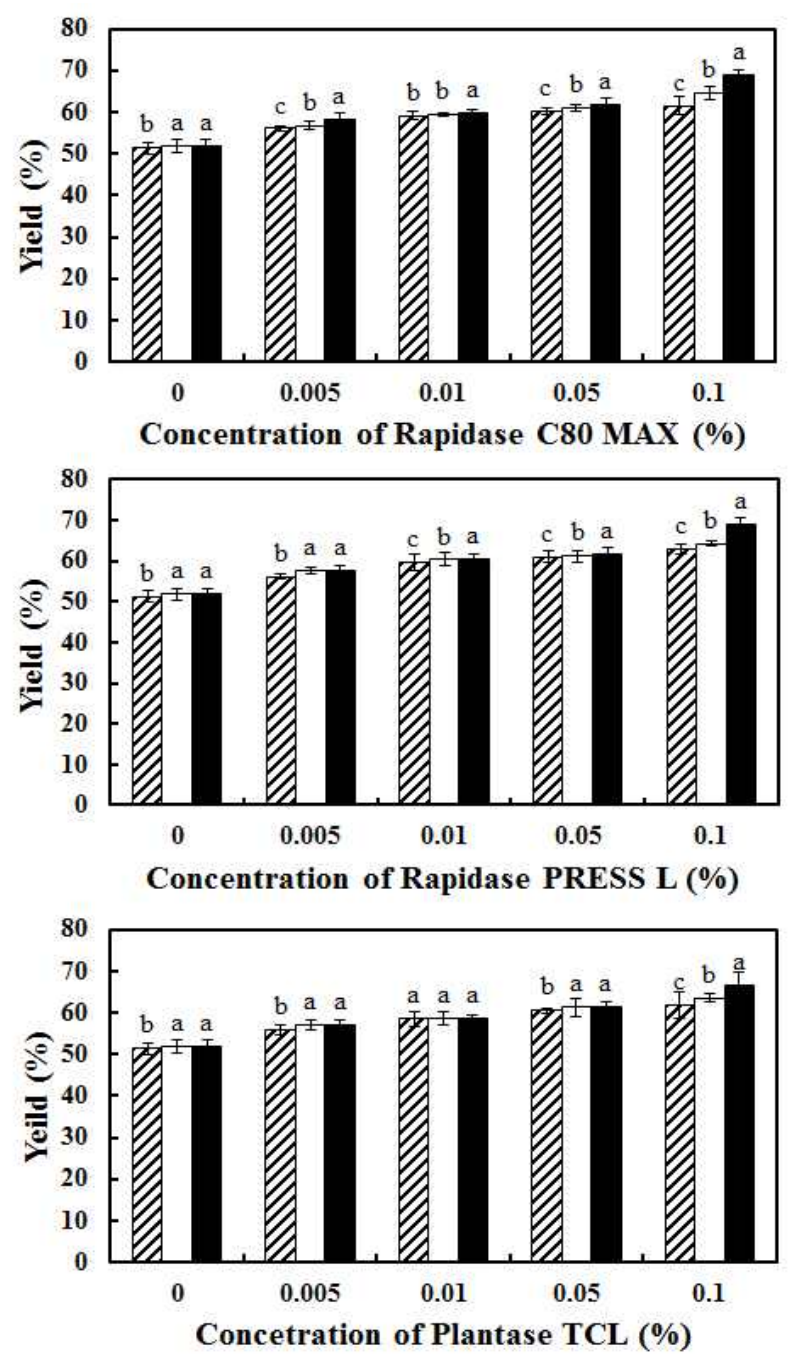

Fig. 1. Extraction of Aronia melanocarpa juice treated with different concentrations of various enzymes at $50^{\circ} \mathrm{C}$ for $120 \mathrm{~min}$.

$\Downarrow, 30 \mathrm{~min} ; \square, 60 \mathrm{~min} ; \mathbf{\square}, 120 \mathrm{~min}$. 
농도인 $0.1 \%(\mathrm{v} / \mathrm{w}), 50^{\circ} \mathrm{C}, 120$ 분 처리 후 Rapidase C80 MAX 은 $68.83 \%$, 그리고 $0.1 \%(\mathrm{v} / \mathrm{w}), 50^{\circ} \mathrm{C}, 120$ 분 처리 후 Plantase $\mathrm{TCL}$ 은 $66.70 \%$ 순으로 각각 나타났다. Rapidase Press PRESS L을 처리한 실험구의 착즙수율이 대조구에 비해 약 $18.1 \%$ 증가한 $69.1 \%$ 로 가장 큰 증가량을 보였다. 이는 $\operatorname{Park}(27)$ 등의 연구결과와 유사하게 Rapidase PRESS L이 pectinase, hemicellulase 복합효소로 구성되어 있어 다른 효 소보다 효과적으로 분해작용이 일어나 수율이 가장 높게 나타났으며, 식물세포벽은 셀룰로오스와 헤미셀룰로오스 등의 골격성분이 펙틴기질에 둘러싸여 있는 구조이므로 셀룰로오스 및 펙틴질 분해효소를 병행사용하면 상승효과 를 보여 세포벽 물질의 분해 및 유용성분의 추출을 촉진하 는 것으로 보고하였다.

\section{효소 처리 최적조건에 따른 $\mathrm{pH}$ 및 총산의 변화}

아로니아 주스의 효소 처리에 따른 $\mathrm{pH}$ 및 총산함량은 Table 2와 같다. Rapidase PRESS L을 처리한 실험구는 가장 높은 $1.23 \%$ 로 측정되었고 그 외 다른 시험구에서도 대조구 에 비해 증가한 값을 나타내었다. $\mathrm{pH}$ 는 모든 시험구에서 3.89-3.93의 수치를 나타내었으며, 효소처리에 따른 $\mathrm{pH}$ 의 큰 변화는 없었다.

Table 2. Contents of total acid and $\mathrm{pH}$ value of Aronia melanocarpa juice treated with $0.1 \%$ of concentration at $50^{\circ} \mathrm{C}$ for $120 \mathrm{~min}$

\begin{tabular}{ccccc}
\hline & Non-treated & $\begin{array}{c}\text { Rapidase } \\
\text { C80 MAX }\end{array}$ & Plantase TCL & $\begin{array}{c}\text { Rapidase } \\
\text { PRESS L }\end{array}$ \\
\hline Total acidity (\%) & $1.05 \pm 0.12^{1)(2)}$ & $1.14 \pm 0.11^{\mathrm{b}}$ & $1.09 \pm 0.21^{\mathrm{c}}$ & $1.23 \pm 0.03^{\mathrm{a}}$ \\
$\mathrm{pH}$ & $3.91 \pm 0.11^{\mathrm{a}}$ & $3.92 \pm 0.22^{\mathrm{a}}$ & $3.89 \pm 0.12^{\mathrm{b}}$ & $3.93 \pm 0.21^{\mathrm{a}}$ \\
\hline
\end{tabular}

${ }^{1)}$ The values were expressed as mean $\pm \mathrm{SD}(\mathrm{n}=3)$.

${ }^{2 n-1}$ Means with different superscript with the column are significantly difference $(\mathrm{p}<0.05)$.

\section{효소 처리 최적조건에 당도 및 환원당의 변화}

최적 효소 처리 조건에 따른 당도 및 환원당의 함량은 Table 3과 같다. 효소 처리를 하지않은 대조구와 비해 약간 높은 14.3-14.5 ${ }^{\circ} \mathrm{Brix}$ 수준의 값을 보였으며, 환원당의 경우 13.34-13.74\%로 대조구 보다 높게 측정되었다. 효소처리에 따른 당도와 환원당은 대구조에 비해 모두 높게 나타났다.

Table 3. Contents of soluble solid and reducing sugar of Aronia melanocarpa juice treated with $0.1 \%$ of concentration at $50^{\circ} \mathrm{C}$ for $120 \mathrm{~min}$

\begin{tabular}{lcccc}
\hline & Non-treated & $\begin{array}{c}\text { Rapidase } \\
\text { C80 MAX }\end{array}$ & Plantase TCL & $\begin{array}{c}\text { Rapidase } \\
\text { PRESS L }\end{array}$ \\
\hline Soluble solid ( ${ }^{\circ}$ Brix) & $14.0 \pm 0.12^{1) 62)}$ & $14.3 \pm 0.12^{\mathrm{a}}$ & $14.4 \pm 0.12^{\mathrm{a}}$ & $14.5 \pm 0.12^{\mathrm{a}}$ \\
Reducing sugar (\%) & $12.08 \pm 0.17^{\mathrm{c}}$ & $13.74 \pm 0.20^{\mathrm{a}}$ & $13.65 \pm 0.18^{\mathrm{a}}$ & $13.34 \pm 0.30^{\mathrm{b}}$ \\
\hline
\end{tabular}

${ }^{1)}$ The values were expressed as mean $\pm \mathrm{SD}(\mathrm{n}=3)$.

${ }^{2) a-c}$ Means with different superscript with the column are significantly difference $(\mathrm{p}<0.05)$.

\section{DPPH radical 소거능의 변화}

항산화 성분이 높다고 알려져 있는 아로니아의 유리 라 디칼 소거 능력을 측정한 결과는 Fig. 2 와 같다. 최적 효소처 리 조건으로 처리한 모든 시험구에서 높은 활성을 나타내었 으나, 대조구로 사용된 $0.1 \%$ ascorbic acid의 측정치인 $79.9 \%$ 보다 낮게 측정되었다. Chung(28)은 black chokeberry 를 $70 \%$ 메탄올로 추출한 후 추출물의 농도가 $3 \mathrm{mg} / \mathrm{mL}$ 인 시험구에서 대구조로 사용된 $1 \mathrm{mg} / \mathrm{mL}$ 농도인 ascorbic acid 와 비교하여 $95.26 \%$ 의 소거능을 확인하였으며, 대조구로 사용된 ascorbic acid의 소거능 $97.48 \%$ 와 대등한 활성을 나 타내었다고 보고하였다. Jeong(29)은 DPPH radical 소거능 을 측정한 결과 아로니아 추출물의 $50 \%$ radical 소거능을 나타낼 때의 반응농도 즉, $\mathrm{SC}_{50}(50 \%$ scavenging activity concentration)값은 $6.15 \pm 0.343 \mathrm{ppm}$ 이었으며 양성 대조군으 로 사용한 ascorbic acid의 $\mathrm{SC}_{50}$ 값인 $9.75 \pm 1.23 \mathrm{ppm}$ 보다 약 1.5 배 우수한 DPPH radical 소거능을 나타내었다고 보고하 였다. 본 연구에서는 효소처리를 시행한 시험구의 DPPH radical 소거능이 대조구인 $0.1 \%$ ascorbic acid에 비해 낮게 측정되었으나 큰 차이는 보이지 않았다.

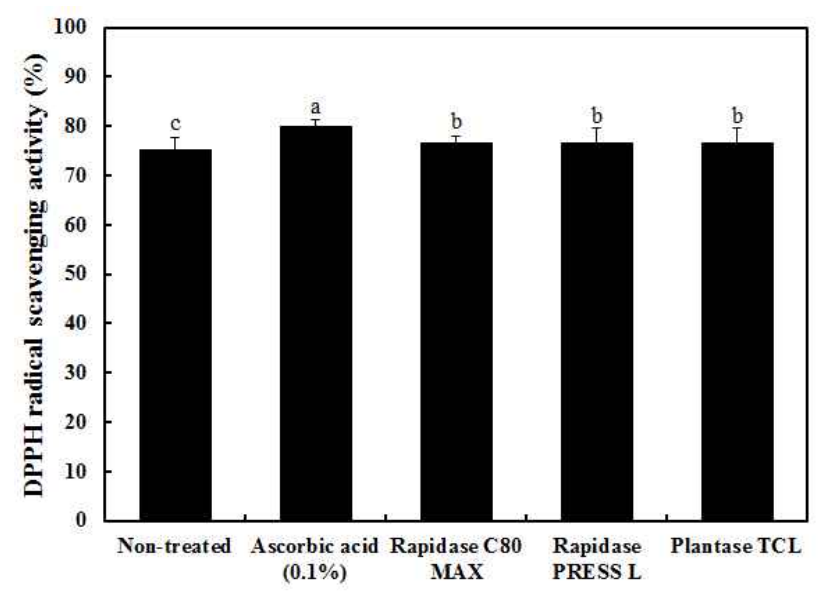

Fig. 2. DPPH radical scavenging activity of Aronia melanocarpa juice after various pectinase enzyme treatments.

\section{총 안토시아닌, 총 페놀성 화합물 함량}

안토시아닌색소는 과실, 채소류에 존재하는 수용색 색소 로 매우 불안정하여 $\mathrm{pH}$, 산소, 금속 등에 의해 쉽게 불안정 해지며, 가공 중 가열이나 이산화황 등의 처리에 의해 변색 이 되기도 한다(30). 아로니아에 함유되어 있는 안토시아닌 은 cyanidin과 결합된 배당체의 형태로 존재하며, 주로 cyanidin-3-galactoside, cyanidin-3-glucoside, cyanidin-3arabinoside, cyanidin-3-xyloside 등 4 개 물질이 보고되고 있 다 $(31,32)$. 아로니아는 재배환경에 따라 폴리페놀함량이 바 뀌는데 동일 품종일지라도 일조량이 풍부하고 토양의 산도 가 $\mathrm{pH}$ 6.50-6.69일 때 좋은 품질의 열매를 얻는다고 보고되 었다 $(33,34)$. 본 연구에 사용된 아로니아의 효소처리에 따 
른 안토시아닌 함량은 Table 4에 나타내었다. 대조구는 $44.14 \pm 1.04 \mathrm{mg} / \mathrm{g}$ 의 값을 나타내었고 Rapidase PRESS L은 $45.48 \pm 0.78 \mathrm{mg} / \mathrm{g}$, Rapidase C80 MAX는 $44.73 \pm 2.07 \mathrm{mg} / \mathrm{g}$ 으 로 대조구에 비해 소폭 상승한 값을 나타내었으며, Plantase $\mathrm{TCL}$ 는 $44.12 \pm 1.38 \mathrm{mg} / \mathrm{g}$ 으로 대조구에 비해 약간 감소하였 으나 큰 차이가 없었다. 아로니아의 착즙수율 향상을 위해 효소처리한 후 총 페놀성 화합물의 함량은 Table 4에 나타 내었다. 효소처리 후 총 페놀성 화합물의 함량은 총 안토시 아닌과 마찬가지로 소폭 증가하였다. 특히, 복합 효소인 Rapidase C80 MAX와 Rapidase PRESS L에서 상대적으로 증가한 값을 보였다.

Table 4. Contents of total anthocyanin and total phenolic compounds of Aronia melanocarpa juice treated with $0.1 \%$ of concentration at $50^{\circ} \mathrm{C}$ for $120 \mathrm{~min}$

\begin{tabular}{ccccc}
\hline & Non-treated & $\begin{array}{c}\text { Rapidase } \\
\text { C80 MAX }\end{array}$ & Plantase TCL & $\begin{array}{c}\text { Rapidase } \\
\text { PRESS L }\end{array}$ \\
\hline $\begin{array}{c}\text { Total anthocyanin } \\
(\mathrm{mg} / \mathrm{g})\end{array}$ & $44.14 \pm 1.04^{1)(2)}$ & $44.73 \pm 2.07^{\mathrm{b}}$ & $44.12 \pm 1.38^{\mathrm{c}}$ & $45.48 \pm 0.78^{\mathrm{a}}$ \\
$\begin{array}{c}\text { Total phenolic } \\
\text { compounds (\%) }\end{array}$ & $0.65 \pm 0.05^{\mathrm{b}}$ & $0.68 \pm 0.06^{\mathrm{a}}$ & $0.65 \pm 0.15^{\mathrm{b}}$ & $0.68 \pm 0.46^{\mathrm{a}}$ \\
\hline
\end{tabular}

${ }^{11)}$ The values were expressed as mean $\pm \mathrm{SD}(\mathrm{n}=3)$.

${ }^{2 \mathrm{k} \cdot \mathrm{C}}$ Means with different superscript with the column are significantly difference $(\mathrm{p}<0.05)$.

\section{요 약}

본 실험은 아로니아의 착즙수율 향상을 목적으로 Rapidase Press L, Rapidase C80 MAX, 그리고 Plantase TCL 3종류의 효소를 사용하여 농도, 온도 및 시간에 따른 착즙수 율을 측정하고 각 효소별 최대 착즙수율 조건을 설정하여 최적 효소처리 후 아로니아 과즙의 이화학적 변화를 조사하 였다. 각 효소별 최적 농도는 $0.1 \%(\mathrm{v} / \mathrm{w})$ 사용 시 최대 수율을 보였으며, 최적 효소반응 온도는 $50^{\circ} \mathrm{C}$ 였으며, 최적 효소반 응 시간은 120 분으로 나타났다. 사용된 효소들 중 pectinase 와 hemicellulase로 구성된 복합효소 Rapidase PRESS L은 효소처리를 하지 않은 대조구보다 $18.1 \%$ 높은 $69.1 \%$ 의 착 즙수율을 보였다. 효소처리를 후 아로니아 과즙의 당도, 환원당, $\mathrm{pH}$, 총산, 총 안토시아닌, 총 페놀성 화합물, 그리고 항산화활성을 조사하였다. 착즙수율 증대를 위한 효소처리 결과, 당도, 환원당, 그리고 총산은 처리전과 비교하였을 때 증가하였으며, $\mathrm{pH}$ 는 효소처리에 따른 큰 변화는 없었다. 총 안토시아닌과 총 페놀성 화합물은 효소처리 후 대구조에 비해 약간 증가하였다. 효소 처리 전후의 아로니아의 항산 화능을 측정하기 위해 DPPH radical 소거능을 측정한 결과 3종류의 효소 모두 대조구에 비해 소폭 상승하였다. 본 연구 를 바탕으로 아로니아 과즙의 착즙수율에 대한 기초 자료로 활용될 수 있으리라 예상하며, 착즙수율이 증가함에 따라
대량 생산 시 수익성도 증가하여 경제적으로도 경쟁력을 가질 수 있을 것으로 사료된다.

\section{감사의 글}

본 연구는 2017년 농촌진흥청 어젠다(PJ012425022017) 과제의 연구비 지원에 의해 수행되었으며 이에 감사드립니 다.

\section{References}

1. Tanaka T, Tanaka A (2001) Chemical components and characteristics of black chokeberry. J Japan Soc Food Sci Technol, 48, 606-610

2. Kokotkiewicz A, Jaremicz Z, Luczkiewicz M (2010) Aronia plants: a review of traditional use, biological activities, and perspectives for modern medicine. J Med Food, 13, 255-269

3. Hwang ES, Lee YJ (2013) Quality characteristics and antioxidant activities of Yanggaeng with Aronia juice. J Korean Soc Food Sci Nutr, 42, 1220-1226

4. Kulling SE, Rawel HM (2008) Chokeberry (Aronia melanocarpa)-A review on the characteristic components and potential health effects. Planta Med, 74, 1625-1634

5. Oszmianski J, Sapis JC (1988) Anthocyanins in fruits of Aronia melanocarpa (Chokeberry). J Food Sci, 53, 1241-1242

6. Kim JY, Park CH (2014) Hair dyeing properties using extracts of Aronia melancocarpa. Kor J Aesthet Cosmetol, 12, 663-668

7. Sin KM (2015) Growth and fruit characteristics of black chokeberry, black currant, elderberry, honeyberry and juneberry introduced into Korea. Ms Thesis, Chonbuk National University, Korea, p 27-35

8. Hendry GAF, Houghton JD (1996) Natural Food Colorants. Blackie Academic and Professional, London, UK, p 33-78

9. Jeong JM (2008) Antioxidative and antiallergic effects of Aronia (Aronia melanocarpa) extract. J Korean Soc Food Sci Nutr, 37, 1109-1113

10. Hou DX (2003) Potential mechanisms of cancer chemoprevention by anthocyanins. Curr Mol Med, 3, 149-159

11. Tsang C, Higgins S, Duthie GG, Duthie SJ, Howie M, Mullen W, Lean ME, Crozier A (2005) The influence 
of moderate red wine consumption on antioxidant status and indices of oxidative stress associated with $\mathrm{CHD}$ in healthy volunteers. Br J Nutr, 93, 233-240

12. Shin DH (2015) Study of the bioactive characteristics of Aronia extract as a cosmatic raw material. $\mathrm{Ph} \mathrm{D}$. Thesis, Konkuk University, Korea, p 36-56

13. Valcheva-Kuzmanova S, Kuzmanov K, Tancheva S, Belcheva A (2007) Hypoglycemic and hypolipidemic effects of Aronia melanocarpa fruit juice in streptozotocin-induced diabetic rats. Methods Find Exp Clin Pharmacol, 29, 101-105

14. Broncel M, Kozirog M, Duchnowicz P, Koter-Michalak M, Sikora J, Chojnowska-Jezierska J (2010) Aronia melanocarpa extract reduces blood pressure, serum endothelin, lipid, and oxidative stress marker levels in patients with metabolic syndrome. Med Sci Monit, 16, CR28-CR34

15. Jurgonski A, Juskiewicz J, Zdunczyk Z (2008) Ingestion of black chokeberry fruit extract leads to intestinal and systemic changes in a rat model of prediabetes and hyperlipidemia. Plant Foods Hum Nutr, 63, 176-182

16. Skoczynska A, Jedrychowska I, Poreba R, Affelska-Jercha A, Turczyn B, Wojakowska A, Andrzejak R (2007) Influence of chokeberry juice on arterial blood pressure and lipid parameters in men with mild hypercholesterolemia. Pharmacol Rep, 59, 177-182

17. Park HR (2014) Antioxidative effect of Aronia melanocarpa on white chocolate ganache. MS Thesis, Sejong University, Korea, p 51-55

18. Chae SY (2015) Effect of Aronia Melanocarpa concentrate on the shelf-life and quality characteristics of beef jerky. MS Thesis, Sookmyung Women's University, Korea, p 49-55

19. Koo JY (2014) Effects of pectinase treatment on the extraction yield and physicochemical properties of blueberry juice. MS Thesis, Kyungpook National University, Korea, p 22-23

20. Jeong EJ (2007) Study on the optimum condition for fermentation of strawberry wine and its quality improvement. MS Thesis, Chonbuk University, Korea, p 53-72

21. Jeong EJ, Kim HE, Shin DH, Kim YS (2007) Effect of pectinase treatment on the extraction yield improvement from Rubus coreanus juice and physicochemical characteristics during alcohol fermentation. Korean J Food Preserv, 14, 702-708
22. AOAC (1990) Official Methods of AOAC international $15^{\text {th }}$ ed, Association of Official Analytical Chemists, Washington DC, USA, p 8-35

23. Miller GL (1959) Use of dinitrosalicylic acid reagent for determination of reducing sugar. Anal Chem 31, 426-428

24. Amerine MA, Ough CS (1980) Method for analysis of musts and wine. Wiley and Sons, New York, USA, p 176-180

25. Blois MS (1958) Antioxidant Determination by the use of Stable Free Radical. Nature, 191, 1199-1200

26. Lee JM, Durst RW, Wrolstad RE (2005) Determination of total monomeric anthocyanin pigment content of fruit juices, beverages, natural colorants, and wines by the $\mathrm{pH}$ differential method: collaborative study. J AOAC Int, 88, 1269-1278

27. Park MK, Kim CH (2009) Extraction of polyphenols from apple peel using cellulase and pectinase and estimation of antioxidant activity. J Korean Soc Food Sci Nutr, 38, 535-540

28. Chung HJ (2014) Comparison of total polyphenols, total flavonoids, and biological activities of black chokeberry and blueberry cultivated in Korea. J Korean Soc Food Sci Nutr, 43, 1349-1356

29. Jeong JM (2008) Antioxidative and antiallergic effects of aronia (Aronia melanopcarpa) extract. J Korean Soc Food Sci Nutr, 37, 1109-1113

30. Kim DH (1998) Food Chemistry. Tamgudang, Seoul, Korea, p 71-79

31. Slimestad R, Torskangerpoll K, Nateland HS, Johannessen T, Giske NH (2015) Flavonoids from black chokeberries, Aronia melanocarpa. J Food Compos Anal, 18, 61-68

32. Jakobek L, Drenjancevic M, Jukic V, Seruga M (2012) Phenolic acids, flavonols, anthocyanins and antiradical activity of "Nero", "Viking", "Galicianka" and wild chokeberries. Sci Hortic, 147, 56-63

33. Djuric M, Brkovic D, Milosevic D, Pavlovic M, Curcic $S$ (2015) Chemical characterization of the fruit of black chokeberry grown on different types of soil. REV CHIM (Bucharest), 66, 178-781

34. Choi KH, Oh HJ, Jeong YJ, Lim EJ, Han JS, Kim JH, Kim OY, Lee HS (2015) Physico-Chemical Analysis and Antioxidant Activities of Korea Aronia melanocarpa. J Korean Soc Food Sci Nutr, 44, 1165-1171 